A Journal of Culture, English Language, Teaching \& Literature ISSN 1414-3320 (Print), ISSN 2502-4914 (Online)

Vol. 17 No. 1; July 2017

Copyright $($ Soegijapranata Catholic University, Indonesia

\title{
Peer Teaching as a Simulation for Communicative Classroom English Rehearsal
}

Atik Rokhayani, Agung Dwi Nurcahyo, Dwi Rukmini, and Ahmad Sofwan

Department of English Education, Universitas Muria Kudus, Indonesia Department of English, Universitas Negeri Semarang, Indonesia

email: atik.rokhayani@umk.ac.id; agung.dwi@umk.ac.id; wiwidwirukmini@yahoo.com; sofwan1589@yahoo.com

Received: 21-08-2017 Accepted: 10-10-2017

Published: 21-10-2017 


\title{
Peer Teaching as a Simulation for Communicative Classroom English Rehearsal
}

\author{
Atik Rokhayani ${ }^{1}$, Agung Dwi Nurcahyo ${ }^{1}$, Dwi Rukmini ${ }^{2}$, \\ and Ahmad Sofwan ${ }^{2}$ \\ atik.rokhayani@umk.ac.id; agung.dwi@umk.ac.id; \\ wiwidwirukmini@yahoo.com; sofwan1589@yahoo.com \\ ${ }^{1}$ Department of English Education, Universitas Muria \\ Kudus, Indonesia \\ ${ }^{2}$ Department of English, Universitas Negeri Semarang, \\ Indonesia
}

\begin{abstract}
One of the professional competences that should be owned by English teachers is classroom English skill since they have to deliver instructions in various classroom context. Consequently, it becomes a challenge for teacher training and education institutions to prepare their student teachers with good English speaking skills for instructional purposes. Student teachers usually have to complete a teaching internship program for one semester at school so as to engage them in a real situation of teaching experience. In that period of time, they will have to use appropriate classroom language when giving instructions to their students. Therefore, student teachers should be provided enough opportinuties for practicing their classroom English skill. In Indonesian English Education Department there is a compulsory course named 'micro teaching class' that should be attended by student teachers before they have a teaching internship program at school. This study aims at describing how peer teaching is practiced by the students of the English Education Department of Universitas Muria Kudus as a simulation activity to use classroom English in delivering classroom's instruction. The study will explore to what extent this simulation can help student teachers improve
\end{abstract}


104 Celt: A Journal of Culture, English Language Teaching and Literature, Volume 17, Number1, July 2017, pp. $103-116$
their communicative competence in classroom instructional process.

Key words: classroom English rehearsal, interactive classroom simulation, peer teaching, communicative competence

Abstrak: Salah satu bagian dari kompetensi profesional yang harus dimiliki oleh guru bahasa Inggris adalah ketrampilan berbahasa Inggris untuk pembelajaran di kelas karena mereka harus menyampaikan beragam instruksi dalam berbagai konteks pembelajaran di kelas. Oleh karena itu, hal ini menjadi suatu tantangan bagi Lembaga Pendidikan Tenaga Keguruan (LPTK) untuk menyiapkan para mahasiswa calon guru dengan ketrampilan bahasa Inggris untuk pembelajaran di kelas dengan baik. Para mahasiswa calon guru harus mengikuti program magang mengajar (Praktek Pengalaman Lapangan/PPPL) selama 1 semester di sekolah-sekolah dalam rangka mendekatkan mereka dengan situasi yang riil dalam bentuk pengalaman mengajar. Pada saat magang di sekolah tentunya mereka harus menggunakan bahasa Inggris untuk pembelajaran di kelas dengan benar. Maka dari itu, para mahasiswa calon guru harus diberi kesempatan yang cukup untuk berlatih menggunakan bahasa Inggris untuk pembelajaran di kelas tersebut. Di Indonesia ada suatu mata kuliah wajib yang harus diikuti oleh para mahasiswa calon guru, yaitu mata kuliah Micro Teaching. Mata kuliah tersebut harus mereka ambil sebelum mereka praktek mengajar di sekolah. Penelitian ini bertujuan untuk mendeskripsikan bagaimana Peer Teaching (Pengajaran Teman Sejawat) dipraktekkan oleh mahasiswa Pendidikan Bahasa Inggris, Universitas Muria Kudus sebagai sebuah kegiatan simulasi penggunaan Bahasa Inggris untuk pembelajaran di kelas. Penelitian ini akan mengeksplorasi sejauh mana simulasi ini dapat membantu para mahasiswa calon guru untuk meningkatkan ketrampilan komunikasi mereka terutama dalam proses pembelajaran bahasa Inggris di kelas.

Kata kunci: latihan berbahasa Inggris untuk pembelajaran di kelas, simulasi kelas interaktif, pengajaran teman sejawat, kompetensi komunikasi 


\section{INTRODUCTION}

A teacher should be a good facilitator in the learning process of EFL class since students need to be encouraged to develop their communicative competence by exposing them in an interactive communication setting. To cope with this demand, it is necessary for Teacher Training and Education Institutions to make their student teachers familiar with some instructional techniques which support their communicative competence. Communicative competence is highly important to be trained to student teachers of EFL class since it has been one of the compulsory competences that should be owned by professional prospective English teachers. They will have to teach English to their students which means they should help their students to communicate in English as a social means of communication. Canale and Swain (1980), Canale (1983) in Celce Murcia and Olshtain (2000, p. 16) proposed that communicative competence could be described as consisting of at least four components: linguistic or grammatical competence, sociolinguistic competence, discourse competence, and strategic competence. It can be perceived that communicative competence help teachers use language in a multidimensional aspect of social interaction that they should introduce to their students. Some instructional methods of EFL, such as Communicative Language Teaching (CLT) and Role Play are necessary to be introduced to student teachers so that they will have inspirations to manage their teaching performance in such a way that interactive classroom can be conducted. Method of Communicative Language Teaching (CLT) is considered to be the remark of paradigm change, from grammatical competence paradigm to communicative competence paradigm (Richard, 2006, p. 3). Role Play is also an effective strategy to bring real social life into classroom which in turn can expose students to an active and interactive learning setting.

An interactive classroom is the one which can engage students to participate in the learning process actively. If a teacher presents an interactive and communicative setting of learning activities, students's disinterest can be avoided. Nurcahyo (2015, p. 1) states, “student's disinterest during a learning process in the classroom is an unexpected case for a teacher since it can make the learning objective of the class unsuccessfully achieved". Student's disinterest occurs because students are not voluntarily attend the class so they need to be encouraged. To encourage students to be involved in the learning activities, students must feel incouraged and open-minded. As a sequence, the teachers should consider their students as growth mindset learners. Morehead (2012) in Heggart (2015) points out Dweck's remark which states, "a growth mindset students understand that their talents and 
abilities can be developed through effort, good teaching and persistence". In line with the paradigm of growth mindset learner, student teachers should also make themselves aware of the importance of being growth mindset teachers because it will enable them to be creative teachers. A creative teacher usually has the sense of making an interactive classroom activities. To be able to conduct interactive classroom setting, a teacher should have powerful communication skill. Powerful communication skill much relies on how teachers use classroom language. It deals with how teachers deliver instructions in the learning process. If the use of classroom language is well managed, teachers will be able to conduct interactive and effective class.

Therefore, student teachers should be provided with intensive training at the campus before they have real teaching activity in the internship program at schools. The intensive training of teaching in English Education Department is usually accommodated in Micro Teaching class. In micro teaching class, student teachers have intensive practice of peer teaching. Love (2012) states, "peer teaching has students take on a teaching role in a school setting in order to share their knowledge with other students". In the English Education Department of Universitas Muria Kudus, a simulation activity in using classroom English in delivering classroom's instruction is practiced by its students as would-be teachers. In this study, it explores to what extent this simulation can help student teachers improve their communicative competence in classroom instructional process. In peer teaching activity, the student teachers are expected to experience learning strategies of Role Play and Communicative Language Teching (CLT) which in turn can make them prepared to conduct interactive class in their teaching internship program at schools.

\section{LITERATURE REVIEW}

This study tries to explore the use of the instructional strategies of Role Play and Communicative Language Teching (CLT) in Micro Teaching class in form of simulation activity of peer teaching. Peer teaching is a kind of classroom role play in which student teachers will play roles of being teachers and students as well. Love (2012) suggests that there are some benefits to peer teaching as follows:

a. Consolidate Learning: By teaching to a peer, students review their own learning, which allows them to strengthen their own knowledge and skills. 
b. Increase Confidence: This type of learning activity boosts self-confidence because students realize that the classroom teacher perceives them as experts and trusts them enough to share their expertise with a peer.

c. Develop Communication Skills: Students must use strong communication skills to be able to provide clear directions, listen to feedback, and then adjust the next set of instructions accordingly so that their peer is successful

d. Assess Learning: The teacher is able to assess students' understanding of the material based on their ability to share their knowledge and skills with a fellow peer, that could not be accomplished using a paper and pencil test.

Peer teaching is expected to be a way to accustom student teachers to intensive rehearsal since they should do a simulation as if they were in a real classroom. Peer teaching also exposes student teachers to a setting of peerreflection with their own friends. This may reduce psychological gap and in turn after the reflection they can make improvement on the way they teach.

The concept and practice of Communicative Language Teaching (CLT) in this study are given to the student teachers in the frame of encouraging them to use classroom English. Student teachers do intensive rehearsal of setting an interactive learning activity through the use of classroom English. This will help student teachers post themselves like in a real situation in a classroom serving as teachers who actively interact with students in an acceptable context of situation by using classroom English. In other chance, they will also be in the position of students that will also be engaged to give response using classroom English. This reciprocal feedback represents the implementation of a classroom simulation by using CLT and role play collaboratively. Therefore, student teachers will have a change of paradigm from teaching the English grammatical competence to English communicative competence paradigm (Richard, 2006: 3). In this case, English grammar is taught without separating it from the contextual use. This approach is expected to condition student teachers to be prepared as creative teachers who always maintain interactive teaching style during their teaching internship program with a perspective of English as social means of communication. Reciprocal model is familiarly perceived to be one of the characteristics of functional approach of language development theory. Hence, students can naturally develop their language proficiency through 
108 Celt: A Journal of Culture, English Language Teaching and Literature,

Volume 17, Number1, July 2017, pp. $103-116$

social interaction in which they construct their communicative competence by using English functionally (Brown, 2007, p. 37).

\section{METHODOLOGY}

The study tries to investigate and describe the practice of peer teaching conducted by the students of the English Education Department of Universitas Muria Kudus as a simulation activity in using classroom English in delivering classroom's instruction. The study will explore to what extent the simulation activity can help student teachers improve their classroom English competence delivering instructions in a role played-teaching practice in Micro Teaching class. It is a also a study which explore the implementation of Communicative Language Teaching (CLT) and Role Play method in developing interactive learning process in the peer teaching activity in which student teachers will take in turns to teach and to be taught. The peer teeching activity will be followed up by a reflection session in which the student teachers have the opportunity to do a self reflection as well as to get criticism, correction and suggestion as well as assessment from one another.

The subject of the research is the student teachers of the English Education Department of Universitas Muria Kudus, Indonesia. The student teachers are students who take Micro Teaching class in the sixth semester in which they are required to take this class as a pre-requisite subject for them to take a teaching internship program in the upcoming semester in a real school. The class is set in a simulation activity of peer teaching as described above. In the peer-teaching activity students will have the following learning experiences:

1. Experience of being a teacher

2. Experience of being students

3. Exerience of using Classroom English

4. Experience of using CLT and Role Play method

5. Experience of peer-assessment on teaching performance

6. Experience of peer-reflection on teaching performance 


\section{Experience of using song, game, and other media of learning}

From the five prospective learning experiences, number 3, 4, 5, and 6 are those which are highlighted in this study. The peer teaching activity applied in micro teaching class are subjected to the curriculum which have until now been implemented in Secondary and High Schools in Indonesia, which are so called Institutional Based Curriculum (KTSP) and Curriculum of 2013. These two curriculum have similarity in the learning approach developed, i.e. both use SCL (Student Centered Learning) approach. CLT and Role Play are methods considered in line with SCL approach. In the same semester the student teachers actually also take the class of Teaching Design for Adult Learner (TDAL). In this class, they get a training to practice designing a lesson plan, methods of teaching, create media of teaching, as well as strategies of teaching in a classroom. The result of the teaching design is then applied in the peer-teaching activity in micro teaching class. Their experience in those courses will help them develop an effective and interactive class.

When the peer-teaching performance is done, a triangular assessment is done by the lecturer as first assessor and two student-teachers serving as first and second assessors. The triangular assessment is done by referring to an assessment rubric which includes the following aspects:

a. How do student-teachers do apperception using classroom English?

b. How do student-teachers deliver the learning material using classroom English?

c. How do the student-teachers relate the material with the real context of daily life using classroom English?

d. How do the student-teachers encourage the participants to actively participate in learning activities using classroom English?

e. How do student teachers create interactive class using classroom English?

f. How do student teachers deliver instructions using classroom English?

g. Does the student-teacher do any follow up of the classroom activities using classroom English?

The above questions cover the aspects on which the observation in the study is based. Those questions, more or less, provide information to describe how 


\section{Celt: A Journal of Culture, English Language Teaching and Literature,}

Volume 17, Number1, July 2017, pp. $103-116$

student-teachers perform communicative classroom English Communicative Language Teaching (CLT) and Role Play method embedded in the simulation of peer teaching.

Peer-reflection on the peer teaching activity is done in the closing session of each meeting of micro teaching class. This activity allows lecturers and other students give evaluation, constructive criticism and suggestions to the teaching performance. Through this activity, student-teachers will be able to grade their performance's quality including the use of classroom English so as to motivate and encourage them to perfom better in the next chance. Efforts to do improvement in a teaching's performance will be evaluated in the following turns of peer-teaching performances, so each student-teacher will have more opportunities to have better performance of using classroom English in a CLT and Role Play based instructional setting. Peer teaching can be perceived as an implementation of a 'socioaffective learning strategy' as proposed by Brown (2007, p. 146). Learning can be done through a cooperation activity in which students are put in a setting of learning in such a way that they can learn together, get feedback from one another, collect information together and designing linguistic activities (Brown, 2007, p. 146).

\section{RESULTS}

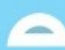

There are 36 student teachers attending the micro teaching class. They are divided into three big groups in order that they can have autonomous learning and practice in group outside the classroom. In the formal schedule, each student is planned to get three opportunities for doing the teaching performance referring to SCL approach as the nature designed in the curriculum of KTSP and the curriculum of 2013. Each teaching performance is assessed by three assessors; those are the lecturer serving as the first assessor and the other two of the student-teachers serving as the second and the third assessor. As the guidelines of assessment, the assessors are given assessment rubric containing the above mentioned points of question as the basis of previewing the extent of the use of classroom English in frame of actualizing CLT and Role Play in the peer-teaching performance. To help the researcher explore the students' responses towards the teaching and learning process, questions in the assessment rubric are used as the reference to grade and perceive the student-teachers' skill in using classroom English and in managing interactive class using CLT and Role Play. 
The study shows that in the beginning period of performance, many student-teachers have not yet optimally applied the CLT method since they seem to have a problem of using classroom English. In fact, the proficiency of classroom English much influence the quality of the teaching performance. The more proficient they are in using classroom English, the more interactive their class will be. It is because CLT demands a communicative instructions so as to encourage students to respond communicatively. In the first period of reflection, the performing studentteachers are then given some criticisms and suggestions by the lecturer and the other student-teachers as the first, second and third assessor. The reflection is done after the student-teachers do the performance. It is conducted so as to boost the improvement of their performance in the next performing session. In this stage, it is found that there are student-teachers or almost $60 \%$ who get low score in instruction delivery management. Based on the observation result most of them do not apply the CLT method well because of their low classroom English proficiency. It is proven by their less interactive class compared with the others. Some student teachers who have high proficiency of classroom English are found to be able to perform more interactive class. They can encourage the students to actively respond to teacher's instructions in English.

In the second period of peer teaching performance, it is found that the student teachers are more encouraged to make the classroom be more interactive. It can be seen from their effort to deliver more communicative and powerful instructions. It is true that there is no significant increase in quality of classroom English performance but at least there is a little change forward on the commitment and their effort to perform more communicative instructions. Based on the assessment, there are still around $50 \%$ of the student teachers who still get low score in classroom English performance but in the reflection session it shows that they are more prepared to conduct the teaching performance with better quality of classroom instructions. After they attend the simulation class of peer teaching, each of them can learn some strong points and weak points of their peer's performance. It is in turn may give motivation and inspiration to them to find and prepare interesting or interactive class. They can peerperceive the teaching performance. If the feedback or response from the class participants (student-teachers serving as the students) are positive so it can be predicted that in the real class at school they will also get positive response from the students. 


\section{Celt: A Journal of Culture, English Language Teaching and Literature, Volume 17, Number1, July 2017, pp. $103-116$}

Meanwhile, in the final stage there is an increase though not significant on the student-teacher's average score of classroom English performance. However, the observation shows that the student-teachers perform more interactive classroom management. Based on the points of questions used by the researcher to assess the teaching quality of the studentteachers, there are several important points, as mentioned above, that should be fulfilled by the student-teachers to be considered as having qualified teaching performance, i.e. how student-teachers use classroom English in the activities, such as management of apperception, delivery of teaching material, level of relevance of the material towards daily life context, encouragement on student's participants in the learning process, creativity on designing interactive class, delivery of instructions and giving follow up activities in the end session of the class. The research result shows that although the average score of classroom English performance does not show a significant improvent, there is a tendency (from the first up to the third stage) toward a growing motivation of making efforts for creative classroom setting. Each of them is motivated and encouraged by their friend's good performance. Additionally, the reflection session has given a supporting drive for them to improve their proficiency of classroom English as the main need to perform interactive English class.

Based on the assessment rubric, observation, and video recording, it shows that the student-teachers have done good efforts to make their teaching performance be positively responded by the classroom participants. Although most of them do not perform good proficiency of classroom Englich, student-teachers cope with that weak point by strenghtening the other aspects of teaching performance such as modifying teachniques, media, and material of teaching. Some student-teachers use teaching methods like cooperative learning, role play, genre based instruction, project based learning and suggestopedia, while regarding the techniques and strategies, most of them use game and group discussion to encourage the students to be active in the class.

Concerning learning media, some media like picture, audiovisual, quiz, games and short story are used by the student-teachers to stimulate the student's participation in the class. It also shows that the student-teachers, along the three stages, have developed efforts to conduct good teaching performance so as to develop interactivity between teacher and students. The observation also reveals that the student-teachers who can manage their method and media of teaching to facilitate the participants (students) to learn English through meaningful classroom activities and real 
communication are those who get good attention (feedback) from the students. It means that whatever the method or media of teaching may be as long as the teachers can create an interactive classroom; the students will be encouraged to participate in the learning activities. It can be stated that if student teachers have good classroom English proficiency, in addition to performing appropriate technique, media and material of teaching, the classroom they design will be better and more interactive.

Although the learning achievement of the students of Micro Teaching class has not reached the expected average score, on the basis of learning process there is a progressive trend of learning outcome since the students get some consolidate learning experiences during the reciprocal teaching practice of the peer teaching activity. The learning experiences that the student-teachers get in the peer-teaching activity in Micro Teaching class are described as follows:

a. Student-teachers experience intensive rehearsal of teaching practice because they will be motivated to make continuous improvement on the teaching quality.

b. Student-teachers have the opportunity to develop their self confidence of teaching. The student-teachers will feel confident when they are given a trust to be the teacher.

c. The public speaking skill of the student-teachers are gradually developed.

d. Student-teachers' communicative competence increase since they are encouraged to practice providing effective instructions, understandable directions, listen to feedback, and etc.

e. The student teachers' literacy can be developed since they are given assignment to prepare teaching material that can be accessed from online or offline resources.

f. There will be no psychological gap among the student teachers when performing classroom English.

g. Triangular assessment practically help students map the scope of evaluation on teaching performance.

h. The reflection session helps the student-teachers improve their weak points of teaching performance in a reciprocal evaluation. 


\section{Celt: A Journal of Culture, English Language Teaching and Literature,}

Volume 17, Number1, July 2017, pp. $103-116$

i. In terms of affective aspect, through the simulation of peer teaching, student teachers feel secured, supported, encouraged and motivated to design an interactive teaching since they feel that they are not alone in learning; they have friends to share and consult with.

From the above learning experiences, it can be pointed out that the three aspects of learning, i.e. affective, cognitive and psychomotoric aspects are stimulated to be able to give contribution on the development of student teachers' teaching performance and classroom English proficiency as well. The learning environment, as the external factor, in micro teaching class gives suggestive drive to the student teachers during the learning process. They have the opportunities to do "trial and error" on teaching performance, to immitate their friends' performance, to compare their strategy with their friends' strategy of teaching and the other reflective learning activities. Thereafter, these external factors nurturally influence the student teachers' motivation of learning, efforts for making improvement, reduction of self inferiority and a drive of developing creativity. It is in line with the theory of behaviourism which maintains the important role of environment in human's effort to improve competence and performance. At this point, it can be seen that in a learning process, students are intensively nurtured by teacher's modelling, instruction, feedback and their friends' performance.

Peer teaching as a classroom model for improving student-teachers' classroom English can be perceived as a learning model which combines the essetials of three approaches in language teaching and learning, i.e. behaviourism, humanism and constructivism though humanism is the most apparent approach in this classroom model. In behaviourism approach, language proficiency is much determined by the extent of the stimulation activity of language performance as a nurturally possessed potential of the students. In this case, students are nurtured by "a learning by doing process" of teaching practice as a form of behaviouristic setting and also stimulated by a peer-working of responding, assessing, suggesting, criticizing and selfreflecting practice as the typical nature of humanistic learning approach (Brown, 2007, p. 13).

When student-teachers conduct the performance of teaching, they are considered as having done the effort of constructing a learning product. To be described in a connecting perspective of learning approach, in the peer teaching activities student teachers have been engaged in the realization of behaviourism, humanism and constructivism. In this point of views, student 
teachers are then finally made aware of the importance of conducting repetition of teaching practice to form a habit of using good classroom English for conducting interactive learning process as seen in behavioursm theory. Student-teachers are put in "a working together learning setting" as commonly suggested by humanism concept. Aditionally, they are encouraged to construct a learning product, i.e. teaching performances as highlighted in constructivism perspective. Overall, student-teachers' classroom language proficiency as a reflection of competence-performance teaching qualification has been intensively rehearsed in a peer teaching activity that is conducted in micro teaching class, in order to prepare them to cope with the qualification of the 21st-Century Teacher. As a 21st century teacher, it is ideal if, a teacher would prepare his/herself as a long life learner, collaborator, innovator, communicator and student facilitator as well as a technology-literate person. (Palmer, 2015).

\section{CONCLUSION}

From the above discussion, there are some concluding points that can be put forward in this article, those are:

a. The peer-teaching performance of the student-teachers in micro teaching class at the English Education Department of Universitas Muria Kudus, has provided opportunities for students' intensive rehearsals of a teaching simulation, to improve their classroom English proficiency;

b. The student-teachers of the micro teaching class have done the efforts to design interactive class as the typical characteristic of teaching strategies;

c. CLT and Role Play have been implemented by the student-teachers in various extent such as modifying material, media, and strategies of teaching;

d. To cope with the problem of classroom English proficiency, student teachers strengthen other aspects of teaching to maintain the interactive activities of the English classroom;

e. Triangular assessment, from lecturer and students, helps student-teachers map the scope of evaluation on their teaching performance; and 
116 Celt: A Journal of Culture, English Language Teaching and Literature,

Volume 17, Number1, July 2017, pp. $103-116$

f. Peer teaching can practically reduce the psychological gap between teacher and students in which in turn will help student-teachers to form a habit and confidence in organizing an active English classroom.

\section{REFERENCES}

Brown, H. D. (2007). Prinsip Pembelajaran dan Pengajaran Bahasa. Jakarta: Pearson Education, Inc.

Celce-Murcia, M. \& Olshtain E. (2000). Discourse and context in language teaching. United States of America: Cambridge University Press.

Heggart, K. (2015). Developing a Growth Mindset in Teachers and Staff. Accessed July 30, 2017 from https://www.edutopia.org/discussion/ developing-growth-mindset-teachers-and-staff

Love, C. (2012). Peer to Peer Teaching - Students Become the Teachers. Accessed July 30, 2017 from http://www.technokids.com/blog/ teaching-strategies/peer-to-peer-teaching-students-become-theteachers/

Morehead, J. "Stanford University's Carol Dweck on the Growth Mindset and Education." OneDublinorg. June 19, 2012

Nurcahyo, A.D. (2015). Creative Teaching for Interactive Classroom. A paper presented in English Education International Conference (EDUTICON), 4-5 November 2015, in Universitas Jambi

Richard, J. C. (2006). Communicative Language Teaching Today. New York: Cambridge University Press. Retrieved on 30 July 2017 from http://faculty.mu.edu.sa/public/uploads/1347871288.356924906 420-Jack-C-Richards-Communicative-Language-Teaching-Today.pdf.

Tsisana, P. (2015). 15 Characters of a 21st Teacher. Accessed August 14, 2017 from https://www.edutopia.org/discussion/15-characteristics-21stcentury-teacher 